\title{
FAMILY - INSTITUTE FOR FORMATION OF SPIRITUAL AND MORAL VALUES
}

\author{
Khayrullayev Chorikul Kazakovich \\ Associate Professor, PhD docent in Department of Medical Chemistry of Bukhara State \\ Medical Institute
}

Khayrullayeva Zuhra Chorikulovna

English language teacher at school №35 of Bukhara city, Uzbekistan

Article DOI: https://doi.org/10.36713/epra4900

\begin{abstract}
ANNOTATION
The article analyzes the essence of the ongoing reforms in the country to strengthen the institution of the family. It also explores the spiritual and educational mechanisms to strengthen the institution of the family, emphasizing the importance of the Eastern thinkers' views on raising children in the family.
\end{abstract}

KEY WORDS- Family, relations with family members, upbringing of a child, cultural heritage.

\section{INTRODUCTION}

Consolidating family values is considered to be one of the basic issues throughout the world. Chief Assembly of United Nations declared on 20september of 1993 that every year 15-may is celebrated as "International family day" in order to strenghten mutual consent of family members. Since then, whole world, especially in Uzbekistan "International family day" is widely celebrated. It should be noted that over the past years in the country a special attention has been paid to the notion of family, its essence and role in society, and all legal frameworks have been created. Significant work has been done to protect the health and interests of women and children. Our country joined the United Nations" Convention on the "Elimination of All Forms of Discrimination Against Women", the International Labor Organization's Convention on "Maternity and Discrimination in Labor and Employment". These documents are a component of a set of legal acts aimed at protecting the interests of women and strengthening their status in the family and society as a whole. Chapter 14 of the Constitution also stipulates that the family is the main unit of society and is under the protection of society and the state. The Family Code and other laws provide incentives for hiring young ladies and women with many children.

\section{MAIN PART}

Women's equality is one of the most important human rights and it is an important prerequisite for ensuring social justice in the country. Unfortunately, at the present stage of human development, there is no single country where women and men are equal in all spheres of life. Inequality is particularly common in developing and poorest families. This creates social, economic and spiritual problems not only for the family, but also for the community. Inequality between women and men is manifested in education, wages and participation in governance. For example:

1. Women make up more than $50 \%$ of the world's population, but possesses only $1 \%$ of the world's property.

2. More than $60 \%$ of the unemployed and uneducated ones are women.

3. Only $20 \%$ of all parliamentarians in the world are women.

4. Women do most of the unpaid house work.

5. Women make up the majority of employment in low-paid jobs in spheres such as education, healthcare, while men are the majority in the most important sectors with high-payment including economy, information technologies. (Abdurahmonov Q. et al.,2017). According to world 


\section{EPRA International Journal of Research and Development (IJRD)}

sociologists, one in every three women in the world has suffered from violence at least once in their lifetime, especially by their husband.

On June 27, 2018 President of the Republic of Uzbekistan Shavkat Mirziyoyev admitted the decree № PP-3808 "On Approval of the Concept of Strengthening the Family Institute in the Republic of Uzbekistan".

At the same time, it is noted that a number of systemic problems and shortcomings that restrain the successful implementation of public policy in this area impede the full implementation of the goals and objectives of strengthening the family institution. For instance, among the disadvantages the poor use of the potential of cultural and historical heritage in the family and educational institutions were also mentioned.

From this point of view, the study of the spiritual heritage of ancestors, their contribution to the historical culture, the scientific interpretation of the ideas of education, and their wide use in the field of education are important for the upbringing of the young generation as a whole.

When we look at history, we see that our ancestors paid much attention to the family. In the works of such great thinkers as Farabi, Beruni, Ibn Sina, Alisher Navoi, Abdurahman Jomiy, special attention is paid to the relationship between family members, the role of parents and family atmosphere in the upbringing of children. They wrote down their stories including their wise words, their letters to youngsters, their conclusion about life and so on. Educated intellectuals such as Mahmudkhoja Behbudi, Abdurauf Fitrat, Abdulla Avloni, Abdulla Kadiri, Cholpon, who lived in the early part of the last century, argued that the only way to raise a harmoniously developed generation is to build the foundations of the family and it is impossible to achieve developed community without strengthening the family.

Abu Nasr Farabi puts his socio-philosophical and political focus at the heart of the study of man, his purposes, and the way to attain moral maturity and happiness. In moral perfection, the philosopher understands good deeds and beautiful human qualities. Negative attitudes that impede moral maturity include laziness, ignorance and worklessness. A perfect man, in the eyes of the scholar, must be knowledgeable, intelligent, justful, honest, humble, good-natured, sociable, dignified, and so on.

Farabi says that man cannot reach maturity alone, he needs to be in contact with others, he always requires help of others and needs to have relationships with them. In particular, Farabi says, "happiness is created in community due to peaceful life, cooperation between people, ideals of a perfect person, and spiritual perfection of people because of their many positive qualities." It is not possible for a man to be happy in himself, it depends on his actions, work, occupation, knowledge. “... (Abu Nasr Farabi et al., 1993).

Just as a person strives for perfection, so does his mind. According to opinions of Farabi this task can be accomplished through the proper training of mind, because the purposeful education improves person not only intellectually but also morally, for instance, if the person is well-versed in the rules of nature and society, he can communicate with others correctly and can find his right way in life. Therefore, Farabi believes that the main task of education is to bring up a person who can meet the needs of society and serve for society. Farabi's views on teaching methods, tools are also valuable. He states that "Human qualities are formed by two ways: education and upbringing. Education can be instructed only due to words and teaching. And upbringing is a practical experience, that is, an action that is made up of people who have the practical skills of that nation. Education combines theoretical qualities, while upbringing combines the inherent qualities theoretical knowledge, practical, occupational and behavioral qualities, while education is formed by words and learning; upbringing is structured by practical work and experience" (Abu Nasr Farabi et al., 1975). Maturity is demonstrated by the combination of both, but it shows that maturity depends on how well you acquire the knowledge and practical skills. Farabi indicated that education combines the study of the theoretical foundations of all disciplines, whereas upbringing deals with the study of moral and ethical principles and ethical standards. Therefore, these ideas should be used to strengthen the educational potential of the family and to improve the spiritual and moral environment in the family.

The great poet, philosopher and statesman of the East, Alisher Navai considered that the role of family is great, especially in society and state in the achievement of physical and spiritual perfection. The most important virtue for a perfect person is donating. It puts the human heart on top of the world, and teaches people to love and value them. Navai appreciates the donation as the most beautiful tree in the "Human Garden" and the most valuable pearl of the "human treasure". Alisher Navai argues that a person's dignity is determined not by his wealth, his career, his social origin, but by his moral character and the extent to which he benefits the people. His words about this are commendable: "If people cannot benefit for others with their words, they should at least have a good heart. They should be glad of the joy of the people." In his "Khamsa" novel, Navai emphasizes the importance of the social environment in human's development. It is scientifically justified by the fact that it is through diligence, cleansing, honesty, and faith. 


\section{EPRA International Journal of Research and Development (IJRD)}

In his book "Family", Abdurauf Fitrat detailed the essence of marriage, rights of parents and children, family relations. While creating the book, Fitrat researched on inhabitants of Bukhara and paid great attention to the style of upbringing of child and stated following sentences: "We appreciate our domestic animals more than our children. Of course our children are the dearest to us. Unfortunately, in spite of all the love and affection, we bring up our children less than our donkeys and sheep! Don't be surprised by my words, be patient and I will prove it. We think that a sheep's perfection is in its fatness and health. The donkey's maturity is in its strength of its feet, and its good conduct. Imagine you buy a lamb or a colt and bring it home. You looking after them carefully, you feed the sheep in a little while, and then you give the donkey strength and that is perfection of them. But you don't train your dear children with such attention. Your excuse is that your child has grown up too. You can argue that we feed our cattle too much, however we need to raise our children with hundred times more strength. Evidence is that if somebody has a domestic animal at home, not any of his animals has been sick during the year, but his child has been diagnosed with illness at least three times for whole year. So it turns out that he paid more attention to his animals than his children ..."(Abdurauf Fitrat et al., 2013).

Indeed, some families are so indifferent to the upbringing of children today that this neglect causes young people to go in different ways and lose their place in society. Abdurauf Fitrat writes: "We need to teach them how to cultivate a sense of selfworth and a sense of dignity and respect for the people around them in order to bring up children as confident, strong, resourceful and intelligent. If a family relationship is based on a strong discipline, the country and the nation are as strong and beautiful." Rizouddin ibn Fakhriddin, in his book "Family", writes about women: "If the family is like a ship, the wife is as the tail of the ship. Just as a ship with a powerful force in the river follows the tail's movement, so in a family the family members follow the wife. In the family if women are educated children are also educated, if women are not educated others also like this, if women are hard-working the whole nation possesses great wealth, if it is on the contrary people also become lazy or extravagant. (Rizouddin Ibn Faxriddin et al., 1991)

Psychologically unhealthy families cause bad effects to social and economical community. Additionally, a child who was born and raised in such psychologically unhealthy environment which is full with conflicts, cruelties and struggles, will become also ruthless and tyrant towards not only his parents, but siblings, neighbourhood and society as well. Futhermore such youngsters will damage increased economics because they turn to be cruel, brutal, selfish, and easily influenced by various negative external forces that are contrary to the interests of the country. That's why they are considered to be dangerous people for their families, their people and their homeland.

The following factors should be considered in the family environment:

- Firstly, the importance of the role of father in the family. Male leadership in life is at the forefront of our mentality. A man must, by his behavior, create an atmosphere in the family and install moral values in his children. Unless the father becomes an exemplar in the eyes of the child, such a marriage will never be perfect. Our nation has always been told, "It is easy to be a father, but it is hard to act like a father." Our children should be proud of their father and follow his deeds;

- Secondly, national values should be on the first stage. Our great ancestors have paid attention to the upbringing, the family and the moral climate in it, and there are numerous works of instruction and ethics in this regard. Among them are "Qabusnoma", "Hikmatnoma", "Qutadgu bilig", "Hayrat ul-abror" and others. The "Hadisi Sharif" also encourages faith and being kind to each other. With the influence of national customs, traditions on the family environment, our children will develop positive qualities.

- Thirdly, mothers should spend much time with raising children. The effectiveness of family training is largely measured by the mother's involvement in this process. The child receives $60 \%$ of its features and capacities from the mother. This is because it is a proven fact that a mother's virtues, spiritual maturity, and intelligence are passed on to the child.

\section{CONCLUSION}

President Mirziyoyev said: "The family is sacred to me. The holiness is that, no matter where they work or who they are, unless people do not take care about emphasis on family education, family atmosphere, honesty in the family, attitudes and upbringing, they will never succeed.

Healthy family environment plays an important role in human development. Healthy environment allows all tasks to be solved correctly, in order to achieve goals and tasks. What youngsters learn from their childhood by watching and listening their parents at home will greatly effect their future. In this process, the use of the ancestral spiritual heritage will serve as a factor for better productivity.

\section{USED LITERATURE}

1. Mirziyoyev Sh.M. (25.07.2018). "About family and happiness".

2. Abdurahmonov Q. (2017). "Human's benefits are the most valuable in Uzbekistan". Tashkent, p.p.:292. 


\section{EPRA International Journal of Research and Development (IJRD)}

Volume: 5 | Issue: 8 | August 2020

- Peer Reviewed Journal

3. Abu Nasr Farabi. (2001). "About qualities, happiness and perfection”. Tashkent, p.p.:40.

4. Abu Nasr Farabi. (1993)."City of unique people". Tashkent, p.p.: 166-167.

5. Abu Nasr Farabi. (1975). "About achieving happiness". Tashkent, p.p.:23-24 .

6. Alisher Navai. (1983). "Mahbub-ul-qulub".

Tashkent, p.p.:59.

7. Abdurauf Fitrat. (2013). "Family". Tashkent, p.p.:72.

8. Rizouddin ibn Faxriddin. (1991). "Family". Tashkent, p.p.: 9 . 